\title{
POTENTIAL VALUES OF BACTERIAL CELLULOSE FOR INDUSTRIAL APPLICATIONS
}

\author{
Endang Sukara ${ }^{1}$, Ruth Meliawati \\ Research Center for Biotechnology, Indonesian Institute of Sciences (LIPI) \\ Jl. Raya Bogor Km 46, Cibinong 16911 - Indonesia \\ 1endangsukara@gmail.com
}

Diterima : 25 Februari 2014, Revisi akhir : 21 Mei 2014, Disetujui terbit : 30 Mei 2014

NILAI POTENSI SELULOSA BAKTERI UNTUK APLIKASI INDUSTRI

\begin{abstract}
ABSTRAK
Selulosa adalah polimer utama di permukaan bumi dan secara internasional menempati kedudukan penting dalam perkembangan ekonomi dunia. Seiring dengan kemajuan ilmu pengetahuan saat ini dan di masa yang akan datang, selulosa, khususnya selulosa murni, memiliki peluang yang sangat luar biasa sebagai bahan baku pada industri makanan modern, industri kesehatan, dan sektor industri lainnya termasuk industri material maju. Saat ini, sumber selulosa utama adalah tanaman. Selulosa yang berasal dari tanaman selalu berikatan dengan lignin dalam bentuk ligonoselulosa yang memiliki kerumitan untuk memisahkannya. Sementara itu, selulosa yang disintesis oleh berbagai jenis mikroba, khususnya bakteri, memiliki keuntungan yang besar karena tingkat kemurniannya yang tinggi, sifat kristal yang lebih baik, mampu menyerap air, polimerisasi yang sederhana, lebih kuat, dan memiliki daya adaptasi biologis yang tinggi. Dalam tinjauan ini, perkembangan terkini dalam proses pengolahan selulosa yang berasal dari bakteri untuk kepentingan pengembangan industri makanan, kesehatan, dan material maju akan didiskusikan.
\end{abstract}

Kata kunci: bakteri,selulosa, kristal-nano, alat kesehatan,komposit-nano, bio-kompatibel

\begin{abstract}
Cellulose is the main biopolymer on earth and internationally plays an important role in global economic arena. Along with the current and the future advancement of science and technology, cellulose, particularly pure cellulose, has an ample of opportunity to be used as raw materials in modern food, health industry and many other industrial sectors including for the production of advance materials. Currently, the main source of cellulose is that of plant origin which naturally interconnected with lignin to forms materials called lignocellulose. Separation of cellulose from lignocellulose is a complicated process. Meanwhile, cellulose which is synthesized by diverse microbial species, especially bacteria, has many advantages. The purity of bacterial cellulose is very high, better crystalline property, high water absorbency, simple polymerization, stronger, and high bio-compatibility. In this review, recent application of bacterial cellulose in the development of food, health industries as well as advance materials will be discussed.
\end{abstract}

Keywords: bacterial cellulose, nano-crystal, medical device, nanocomposite, biocompatible

\section{INTRODUCTION}

Cellulose is the earth's major biopolymer and is of tremendous economic importance globally (Keshk and Sameshina, 2006). A homopolymer type of $\beta$ (1-4) linked glucose, is the most abundant cellulose structure found naturally on earth with vascular plants being the major source (Brown, 2004). Cellulose is considered as an inexhaustible source of materials for a wide number of application (Huber et al., 2006). It is an important raw material in food, health, and 
many other manufacturing industries includes among other advance material and energy. The major problem found in plant-derived is for its highly bound to lignin, forming lignocellulose. Cellulose fiber has to be first separated from lignin if it is going to be use as feedstock in cellulose based-industry. The separation of cellulose from lignin is, however, not an easy task. It needs sophisticated technology and requires significant amount of energy input. Separating cellulose is, therefore costly and in many cases, becomes the bottle neck in cellulose based-industry. Cellulose from higher vascular plants has been used in the manufacturing of paper and textile for millennia (Hon, 1994). For this purpose, separation process of cellulose from lignocelluloses in paper and textile industry is mandatory. Physical and chemical processes are widely used. But it causes severe toxic chemical pollution of river and lake and lead to the degradation of environment and eventually reduces health quality.

On the other hand, bacterial cellulose has higher purity, excellent crystalline property, good water absorption, better tensile strength, ultra fiber networks with diameter of 20-100 nm, low degree of polymerization and stronger biological adaptability (Bläckdahl et al., 2006; Klemm et al., 2006; Iguchi et al., 2000; Wan et al., 2006). In the use of bacterial cellulose do not need physical and chemical processes that could cause pollution. Bacterial cellulose should be an excellent choice as a feedstock for manufacturing cellulose based products (Castro et al, 2011). Bacterial cellulose with new approaches has a wide application in different commercially important sectors not only food, textile, and paper industry, composite membranes, medicine, biomedical material, bioadsorbent material and loud speaker diaphragms (Wan et al., 2006 and Oshima et al., 2011). It is also possible to use bacterial cellulose as a scaffold material (Bläckdahl et al., 2008) and bionanocomposite (Nainggolan et al., 2013).

There are number of bacterial genera able to produce cellulose. Those genera include among others Gluconacetobacter (formerly Acetobacter), Agrobacterium, Aerobacter, Achromobacter, Azotobacter, Eschirichia, Rhizobium, Salmonella, and Sarcina (Ross et al., 1991; Naritomi et al., 1998; Rezaee et al., 2008; Sani and Dahman, 2010; Moosavi-Nasab and Yousefi, 2011; and Norouzian et al., 2011;). Alcaligenes and Pseudomonas were also reported to synthesize cellulose (Deinema et al., 1971).
Acetobacter xylinum, however is one of the most extensively studied as source of bacterial cellulose (Naritomi et al., 1998; Sheykhnazari et al., 2011; and Zeng et al., 2011). Therefore, it is the aim of this paper to review the production of bacterial cellulose, its application in food, health, and materials industry.

\section{FOOD APPLICATION}

The applications of bacterial cellulose was reported by Sanchez (1994). With more uses and more innovative recipes being invented, bacterial cellulose based products continue to grow and gain its popularity as a natural high fiber food. It is now becoming a part of health food and diet. The tasteless and unique texture makes bacterial cellulose a versatile ingredient for main dishes as well as juices, and other beverages, confectionaries, ice cream, yoghurt, salad, dessert, and baked items. Okiyama et al. (1992) reported that the gelatinous cellulose is composed of $0.9 \%$ bacterial cellulose and $99.1 \%$ water wherein the water content is composed of $0.3 \%$ bound water and $89.7 \%$ free water. The feature of gelatinous cellulose compared with ordinary food hydrocolloids, is in the syneresis and gel strength. The syneresis characteristic is due to the water in the gelatinous cellulose that is kept with the cellulose fibrils by capillary actions but when this water is immobilized, the texture becomes modified rendering it applicable to processed foods.

Okiyama et al. (1992) have shown that when the gelatinous gel produced by Glucanobacter xylinus under static liquid culture was processed with sugar alcohols, the texture is comparable to grape which makes the product is applicable for salads, low calorie desserts and other food items. When alginate is added during processing, the texture is comparable to that of the squid. This property is very much suitable for the fabrication of diverse food products. Bacterial cellulose can be further processed and suspended in liquid form. This approach was probably based on the high water holding capacity of the cellulose gel which was found to be more than 100 times that of its dry weight. Bacterial cellulose gel can be disintegrated to form a paste-like material which swells and disperse homogenously when water is added (Okiyama et al., 1992). This paste-like material has smooth texture, high water holding capacity, and heat stability which can add body 
to fragile food hydrogels, reduce stickiness of pasty foods and serve as non-caloric bulking agent. Furthermore, the paste-like cellulose material in food formulations was achieved in chocolate drink, pasty condiment like seasoned clam extract, ice cream, tofu (soybean curd), kamaboko (boiled fish paste) and low-calorie products such as hamburger patty, sausage and a Japanese red bean jam (Okiyama et al., 1992). When added in chocolate drink formulation at the concentration of $0.5 \%$, the bacterial cellulose prevented the precipitation of cocoa powder by trapping it in the microfibrillar mesh resulting to increased viscosity of the beverage. Bacterial cellulose was found to be more effective than xanthan gum in heated non-oil food formulations. The bacterial cellulose also improved the physical property of semisolid foods or pasty seasonings by reducing its stickiness and imparting body to the preparation making it more acceptable for commercial production. In case of ice cream with added $0.5 \%$ bacterial cellulose, the time to reach the melting point at room temperature was prolonged. Okiyama et al. (1993) reported the hamburger formulation was replaces with one third of the beef requirement by mixture of bacteria cellulose paste and beef extract producing a product with $25 \%$ decreased energy value without affecting tenderness and juiciness.

Shi et al., (2013) illustrated further the advantages of biocellulose in food industry. It is well established as dietary fiber which offers a range of health benefits and can assist to reduce the risk of chronic diseases such as diabetes, obesity, cardiovascular diseases and diverticulitis. Bacterial cellulose which is produced by microorganisms is highly in the pure form and does not require harsh chemical treatments to isolate and purify as is necessary for cellulose derived from plant sources. Bacteria can utilize a culture medium resource such as fruit syrup to grow, reproduce and secrete in situ the flavor and colour of the medium. Bacterial cellulose cultured in these medium can acquire the nature flavor and pigment of the fruit. The type of cellulose can be produced in a range of shapes and texture, such as films, multi-shaped pulps, filaments, spheres, particles, and whiskers suited to many different applications in food industries. The fibers are within the nano-scale with a fine three-dimensional network structure, which enables bacterial cellulose to be used in novel food manufacturing processes.
Bacterial cellulose gel, named nata is a traditional dessert in Southeast Asia. Due to the smooth mouth feel and simple manufacturing process, this food has become very popular and is now quickly spreading worldwide. It can improve the rheology of food which is important to avoid flavor interaction, enhance the stability of food over a wide range of $\mathrm{pH}$ 's, temperature and freeze-thaw conditions. It has potential application as thickening, gelling, stabilizing and water-binding. Bacterial cellulose can be used as prominent ingredient in low-calorie food products and can be used as an important ingredient in the production of low-cholesterol products. Another application is in an active food packaging industry where it can increase or confirm the shelf life or safety of products. Antimicrobial agents, oxygen and ethylene scavengers, moisture removers and taint removers may also be integrated with biocellulose based active food packaging systems (Shi et al., 2013).

\section{MEDICAL APPLICATIONS}

White and Brown (1989), Brown (1992), and Yamanaka (1989) reported, that bacterial cellulose has high crystallinity, high purity (free of lignin and other biogenic products), high water-absorption capacity, and high mechanical strength in wet state. Those properties inspired many researchers to develop new application of bacterial cellulose in medical fields.

Kulkarni et al., (2012) conducted experiment on the use of bacterial cellulosed as an alternative for pharmaceutical excipient in drug formulation. It was shown clearly that bacterial cellulose has smaller size compare to the commercial product, AV101. It is densely packed, reticulated structured consisting of fine thread like fibrils, high bulk density, better flow property, lesser elastic recovery and higher tensile strength. It is concluded that bacterial cellulose is an excellent pharmaceutical excipient in the formulation of tablet and can provide a less inert tablet and give suitable consistency of the tablet.

Bacterial cellulose has been established as a remarkably versatile biomaterial and can be used in wide variety of applied scientific endeavors, especially for medical devices. Bacterial cellulose based biomedical devices recently have gained a significant amount of attention because of increased interesting tissue-engineered products. The architecture of bacterial cellulose 
materials can be engineered over length scales ranging from nano to macro by controlling the biofabrication process which bring a vital role in in vivo performance of biomaterials. Gamma irradiation treatment could modify the bacterial cellulose surface properties and enhancing its potential for biomedical applications (Gabriel et al., 2013). Physical modification of bacterial cellulose is believed to be one of the future alternative routes for Transdermal Drug Delivery.

Cook (2013) found out that bacterial cellulose produced by acetic acid bacteria Gluconacetobacter xylinus is ideal vehicle for drug delivery and related biomedical functions. It is FDA approved for internal applications. Bacterial cellulose is non-toxic to endothelial cells and has little effect on blood profiles. Conjugation of therapeutics to bacterial cellulose can be accomplished through the available alcohol groups of the anhydroglucose units (AGU), making targeted delivery possible. When amine was introduced to bacterial cellulose through a reaction involving epichlorohydrin and ammonium hydroxide, the protein horseradish peroxidise (HRP) was conjugated to aminatedbacterial cellulose. Furthermore, Cook (2013) demonstrated that hydrogen peroxide can hydrolyze bacterial cellulose and nanocrystalline cellulose (NCC-BC) can be created. The NCC$\mathrm{BC}$ is capable of intracellular delivery. When amine is introduced to NCC-BC, the conjugation of HRP can be optimized. Anavidin-biotin glucose oxidase and avidin-biotin $\beta$-galactosidase complex may be conjugated to aminated NCC$\mathrm{BC}$ and the application of aminated NCC-BC as a carrier of therapeutic proteins.

Bacterial cellulose membranes are also used as the carrier for berberine hydrochloride and berberine sulphate to produce a new controlled release system. It can significantly extend drug release time and the freeze-dried bacterial cellulose membranes with $10 \mathrm{~mm}$ thick can optimize drug delivery (Huang et al., 2013). They also found that the lowest release rate was in simulated gastric fluid ( $\mathrm{SGF}$ ) or in $\mathrm{H}_{2} \mathrm{SO}_{4}$ solution and the highest rate was in simulated intestinal fluid (SIF) and an intermediate rate was in alkaline conditions. Scanning electron microscopy (SEM) analysis demonstrated that bacterial cellulose fibers were swollen in acid and base conditions. High-resolution magic angle spinning nuclear magnetic resonance $(1 \mathrm{H}$ HRMAS NMR) diffusion-ordered spectroscopy
(DOSY) analysis showed that there was an interaction between the drugs and bacterial cellulose. The structure of bacterial cellulose, the media and the solubility of the drug all influenced the sustained-release behavior. Furthermore, the nano-cellulose 3D-network could controlledrelease drug carries.

In the medical field, bacterial cellulose can be used to treat, as temporary skin substitute, skin wound and second and third degree burns, as a surgical wipe, treatment pad, burn bandages or tissue/organs drape (Ring et al., 1986; Fontana et al., 1990). Bacterial cellulose has an ultrafine and highly pure nanofibril network structure and it can be used as an efficient wound-healing platform since cell migration into a wound site is strongly meditated by the structural properties of the extracellular matrix. The fabrication of a nanofibrillar patch by using bacterial cellulose and its application as a new wound-healing platform for traumatic tympanic membrane (TM) perforation was demonstrated by Kim et al., (2013). TM perforation is a very common clinical problem worldwide and presents as conductive hearing loss and chronic perforations. The bacterial cellulose nanofibrillar patch can be synthesized from Gluconacetobacter xylinus; it was found that the transparent patch contained a network of nanofibrils. The thickness of the bacterial cellulose nanofibrillar patch was approximately $10.33 \pm 0.58 \mu \mathrm{m}$, and the tensile strength and Young's modulus of the bacterial cellulose nanofibrillar patch were $11.85 \pm 2.43$ and $11.90 \pm$ $0.48 \mathrm{MPa}$, respectively. Therefore, satisfying the requirements of an ideal wound-healing platform for TM regeneration. In vitro studies involving TM cells showed that TM cell proliferation and migration were stimulated under the guidance of the bacterial cellulose nanofibrillar patch. In vivo animal studies demonstrated that the bacterial cellulose nanofibrillar patch promotes the rate of TM healing as well as aids in the recovery of TM function. It was demonstrated that the bacterial cellulose nanofibrillar patch is a useful woundhealing platform for TM perforation (Kim et al., 2013). The treatment using Biofill relieves pain has the advantages of good adhesion, effective barrier to infection, fast healing, good fluid (water and electrolyte) retention, low cost, and short treatment time as normal, healthy skin grows to replace the artificial skin substitute. Lin et al., (2013) used combination of microbial cellulose and chitosan to form bacterial cellulose-chitosan 
membranes for wound dressing. The tensile strength of this membrane was slightly lower but the wound was regenerated faster. The use of microbial cellulose-chitosan membranes was considered as a potential candidate for wound dressing materials.

Bacterial cellulose is becoming a remarkably versatile biomaterial and it can be used in wide variety of applied scientific endeavours, especially for medical devices. Biomedical devices recently have gained a significant amount of attention because of an increased interest in tissue-engineered products for both wound care and the regeneration of damaged or diseased organs. Due to its unique nanostructure and properties, microbial cellulose is a natural candidate for numerous medical and tissueengineered applications. Hydrophilic bacterial cellulose fibers of an average diameter of $50 \mathrm{~nm}$ were produced by the bacterium Acetobacter xylinum, using a fermentation process. The microbial cellulose fiber has a high degree of crystallinity. Using direct nanomechanical measurement we can determine that these fibers are very strong and when used in combination with other biocompatible materials, we can produce nanocomposites suitable for use in human and veterinary medicine. The nanostructure and morphological similarities with collagen make bacterial cellulose attractive for cell immobilization and cell support. The architecture of bacterial cellulose materials can be engineered over length scales ranging from nano to macro by controlling the biofabrication process. Modification of microbial cellulose can increase the compatibility between cellulosic surfaces and a variety of plastic materials. Intensive study provides deep knowledge of fascinating current and future applications of bacterial cellulose and their nanocomposites especially in the medical field, materials with properties closely mimic that of biological organs and tissues (Cherian et al., 2013). Bacterial nanocellulose is recognized as a novel non-degradable biocompatible material that promotes chondrocyte adhesion and proliferation (Nimeskern et al., 2013). The mechanical property of bacterial nanocellulose is closed to the properties of native ear cartilage. Bacterial nanocellulose, therefore can be used for ear cartilage and biofabrication to produce patient-specific bacterial nanocellulose based ear cartilage for ear cartilage replacement. Bacterial nanocellulose based air cartilage can now be produced in patient-specific ear shapes and implants can be carried out safely (Nimeskern et al., 2013). Following a specific modification process a cartilage-like material for restoration of damaged tissues, nanocellulose biocompatible products can now be produced. This product can be implanted with excellent biocompatibility, mouldability, biophysical and chemical properties perfectly fit the needs of reconstructive surgery (Kowalska-Ludwicka et al., 2013). In vivo experiment, shows that nanocellulose could guide the reconstruction of damaged peripheral nerves. Cellulosic neurotubes can effectively prevent the formation of neuromas. This material is very good biocompatibility and allow the accumulation of neurotrophic factors and thus facilitating the process of nerve regeneration (Kowalska-Ludwicka et al., 2013).

The culture of multipotent mesenchymal stem cells on natural biopolymers holds great promise for treatments of connective tissue disorders such as osteoarthritis. The safety and performance of such therapies relies on the systematic in vitro evaluation of the developed stem cell-biomaterial constructs prior to in vivo implantation. Bacterial cellulose is a biocompatible natural polymer which can be developed as a scaffold for equinederived bone marrow mesenchymal stem cells (EqMSCs) for application in bone and cartilage tissue engineering. Lyophilized bacterial cellulose hydrogel scaffolds were cytocompatible to support cellular adhesion and proliferation, as well as allowed for osteogenic and chondrogenic differentiation of EqMSCs. The cells seeded on the bacterial cellulose hydrogel were shown to be viable and metabolically active. These findings demonstrate that the combination of a bacterial cellulose hydrogel and EqMSCs are promising constructs for musculoskeletal tissue engineering applications (Favi et al., 2012).

Geyer et al. (1994) developed a process in the preparation of hallow-shaped bacteria cellulose which is useful as substitute for medical materials such a blood vessel, lymphatic vessel, ureter and trachea.

\section{INDUSTRIAL APPLICATIONS}

Nanofibers and bio-nonwoven fabrics of pure cellulose can be made from some bacterial cellulose. Bacterial cellulose fibers are very pure, $10 \mathrm{~nm}$ in diameter and about 0.5 micron long. The molecular formula of bacterial cellulose is similar 
to that of plant cellulose. Its fibers are very stiff and it has high tensile strength, high porosity, and nanofibrillar structure. Biocellulose can potentially be produced in industrial quantities at greatly lowered cost and water content, and with triple the yield by a new process. Ashjaran et al., (2013), critically reviewed bacterial cellulose as a biological nonwoven fabric with special emphasis on its fermentative production and its applications. It is quite clear that bacterial cellulose biofabric with respect to its structure and physicochemical properties has a great potential application in textile, nonwoven cloth, paper, films, synthetic fiber coating in addition to food and pharmaceutical industry.

Yamanaka (1989) reported that the utilization of bacterial cellulose for several industrial products was due to its remarkably high modules of elasticity, high internal loss, low density and high sound propagation velocity. The young modulus of a sheet prepared by squeezing and drying alkaline treated gelatinous gel of bacterial cellulose was about 30 Gpa (Nishi et al., 1990). Some of the product produced from bacterial cellulose sheet replaced the traditional materials for electroacoustic transducers such as loudspeakers and headsets. The bacterial cellulose sheet was found to have better physical characteristics required for the manufacturing of electroacoustic transducers products. Reported by Kent et al. (1991) that a microbial cellulose product with a trade name Cellulon, is economically produced in agitated fermentor. Its application are in food, medical and industrial products. It has a number of potential industrial application such as binder for ceramic powders and minerals, thickeners for paint, ink, adhesives and even as paper coating (Cannon and Anderson, 1991). Several studies reported that bacterial cellulose is seen as a potential new material for use in the production of quality paper (Johnson and Winslow, 1990), paint additives (Cannon and Anderson, 1991) and ultra filtration membrane (Takai et al., 1991).

Bionanocomposites materials are emerging as a viable alternative with an increasing scientific and industrial interest due to their versatility towards potential application (Ruiz-Hitzky et al., 2007). Bacterial cellulose has been recently investigated as an attractive environmentally friendly material for the preparation of nanocomposites. Bacterial cellulose is a natural nanomaterial which consists of a micro-porous
3D network structure of ribbon-shaped cellulose nanofibrils (Iguchi et al., 2000) with high specific surface. Its properties are combined with good biocompatibility, high tensile strength, high water content up to $99 \%$, and high crystalinity (of $70-$ $80 \%$ ) (Hsieh et al., 2008). Those make bacterial cellulose a potential material for applications in different fields such as the industries of paper and textiles, optically transparent composites, substrates for OLEDs, e-paper (Klemm et al., 2001; Nogi and Yano 2008; Czaja et al., 2004; Maneerung et al., 2008). Bacterial cellulose was used as a template to design hybrid inorganicorganic composites. It combines the excellent properties of bacterial cellulose with optical, magnetic, electrical and chemical properties of inorganic nanoparticles (Gutierrez et al., 2013). Bacterial cellulose may be used as continuous nanoporous matrix to fabricate hybrid nanopaper or thin membrane. This cellulose has potential applications in tissue engineering (Wan et al., 2007), liquid filtration and purification (Ye et al., 2003), solar cells (Makela et al., 2007) and electronic devices (Siró and Plackett, 2010). Bacterial cellulose membrane was used to develop hybrid nanopapers by the addition of sol-gel titanium and/or vanadium oxides nanoparticles. This process is claimed to be the simplest and most versatile method to design hybrid materials with properties engineered at the nanoscale. Fabricated hybrid inorganic/organic nanopapers modified with vanadium and titanium oxide nanoparticles had potential application as sensitive displays, biosensors and other optical devices (Gutierrez et al., 2013).

The conductive properties of bacterial cellulose in combination with $\mathrm{TiO}_{2}$ were studied. It forms $\mathrm{TiO}_{2}$ /bacterial cellulose hybrid $\left(\mathrm{TiO}_{2} /\right.$ $\mathrm{BC})$ nanoparticles which is a hybrid of inorganic/ organic fibers. Bacterial cellulose act as hydrophilic substrate and $\mathrm{TiO}_{2}$ nanoparticles were located on the surface of bacterial cellulose due to hydrogen bonding interactions. Amorphous neat $\mathrm{TiO}_{2}$ were electrically neutral and consequently do not respond to the applied voltage. But $\mathrm{TiO}_{2} / \mathrm{BC}$ hybrid composites indicate that $\mathrm{TiO}_{2}$ nanoparticles are able to respond on the voltage applied. This hybrid advance nano product do have a good conductivity properties (Guitierrez et al., 2012).

It is now possible to produce ultralight, flexible, and fire resistant carbon nanofiber aerogels in large scale from bacterial cellulose pellicles 
(Wu et al., 2013). When this product is used as absorbents, it can absorb a wide range of organic solvents and oils with excellent recyclability and selectivity. The absorption capacity can reach up to 310 times the weight of the pristine carbon nanofiber aerogels. This should be a great potential in combating organic and oils pollution. The electrical conductivity is highly sensitive to the compressive strain, thereby making it a potential pressure-sensing material. Other potential application of bacterial base carbon nanofiber aerogel may include 3D electrode materials for lithium-ion batteries and super-capacitors, catalyst supports, and advanced sensors.

\section{CONCLUSION}

As mega diversity country, Indonesia should have a great opportunity to find diverse microbial cellulose producers and participate in the global biocellulose based industrial development. Currently, the production of biocellulose is widely practiced in Indonesia. Unfortunately, the raw material for the production of biocellulose is limited to coconut water and the use of biocellulose is limited to biocellulose gel which is widely known as nata de coco, an excellent cocktail ingredients. The advancement of sciences provided in this review articles, clearly shown that biocellulose application is expanded tremendously. For Indonesia, there are ample of opportunity to advanced this technology by finding better microbial strains of Indonesian origin and explore the possibility of using diverse feedstock including sap from nipa, lontar, gewang, and other raw materials which are abundantly available in the country. It is timely for Indonesia to boost new and more advance food and health industry and open new opportunities in the developing of diverse biocellulose-based products including the production of new advance nano biocellulose and nano biocellulose hybrid with its new application for the prosperity of the nation and the benefit of human civilization.

\section{ACKNOWLEDGEMENTS}

I would like to thank Research Institute for Sustainable Humanosphere (RISH), Kyoto University in providing opportunity to work at RISH Kyoto University as Visiting Scientist between September 2013 and February 2014. I also thank to the Indonesian Institute of Sciences
(LIPI) for allowing me to participate in this program.

\section{REFERENCES}

Ashjaran, A., M. E. Yazdanshenes, A. Rashidi, R. Khajavi, A. Rezaee, 2013. Overview of bionanofabric from bacterial cellulose. Journal of the Textile Institute. Vol. 104, No. $2,121-131$

Bläckdahl, H., M. Esguerra, D. Delbro, B. Risberg, and P. Gatenholm. 2008. Engineering microporosity in bacterial cellulose scaffolds. Journal of tissue engineering and regenerative medicine. No. 2, 320 - 330

Bläckdahl, H., G. Helenius, A. Bodin, U. Nannmark, B. Johansson, B. Reisberg. 2006. Mechanical properties of bacterial cellulose and interactions with smooth muscle cells. Biomaterials. No. 27, $2141-2149$

Brown, Jr. R. M. 1992. "Emerging technologies and future prospects for industrialization of microbially derived cellulose". In: Harnessing Biotechnology for the 21st Century, Ed. Ladisch, M. R. and A. Bose, Proceedings of the Ninth International Biotechnology Symposium and Exposition. Crystal City, Virginia. American Chemical Society, Washington, D. C. pp 76-79

Brown, R. M. 2004. Cellulose structure and biosynthesis; what is in store for the $21^{\text {st }}$ century? Journal of Polymer Science Part A: Polymer chemistry. No. 42, 487 - 495

Cannon, R. E. and S. M. Anderson. 1991. Biogenesis of bacterial cellulose. Critical Rev. Microbiol., Vol. 17, No. 6, 435-447

Castro, C., R. Zuluaga, J. L. Putaux, G. Caro, I. Mondragon, and P. Ganan. 2011. Structural characteristics of bacterial cellulose produced by Gluconacetobacter swingsii sp. from Columbian agroindustrial wastes. Carbohydrate Polymers. No. 84, 96-102

Cherian, B. M., A. L. Leáo, S. F. de Souza, G. M. de Olyveira, L.M. M. Costa, C. V. S. Brandao and S. S. Narine. 2013. Bacterial nanocellulose for medical implants. Advances in Natural Polymer Advanced Structural Materials. No. 18, 337 - 359.

Cook J. R., 2013, "Amine fungtionalization of bacterial cellulose for targeted delivery applications", Thesis, Graduate Program in Biomedical Engineering, School of Graduate and Postdoctoral Studies, The University of Western Ontario, Ontario, Canada

Czaja, W. D. Romanovicz, R. M. Brown. 2004., Structural investigations of microbial cellulose produced in stationary and agitated culture. Cellulose No. 11, $403-411$ 
Deinema, M. H. and L. P. T . M. Zevenhuizen. 1971. Formation of cellulose fibrils by gramnegative bacteria and their role in bacterial flocculation. Ach. Micribiol., No. 79, 42-57

Favi, P. M., R. S. Benson, N. R. Nielsen, R. L. Hammonds, C. C. Bates, C. P. Stephens and M. S. Dhar. 2013. Cell proliferation, viability, and in vitro differentiation of equine mesenchymal stem cell seeded on bacterial cellulose hydrogel scaffolds. Materials Science and Engineering C., No. 33, 1935 1944

Fontana, J. D., A. M. Souza, C. K. Fontana, I. L.Torriani, C. Moreschi and B. S. Gallotti 1990. Acetobacter cellulose pellicle as temporary skin substitute. Appl. Biochem. Biotechnol., Vol. 24, No. 25, 253-264

Gabriel, M.O., M. M. C. Ligia and B. Pierre. 2013. Physically modified bacterial cellulose as alternative routes for transdermal drug delivery. Journal of Biomaterials and Tissue Engineering, Vol. 3, No. 2, 227 - 232

Geyer, U., T. Hernzi, A. Stein, D. Klemm, S. Marsch, D. Schumann, and H. P. Schmauder. 1994. Formatoin, derivatization and applications of bacterial cellulose. Int. J. Biol. Macromol., Vo. 16, No. 6, 343-345

Guitierrez, J. A. Tercjak, I. Algar, A. Retegi. I. Mondragon. 2012. Conductive properties of $\mathrm{TiO} 2 /$ bacterial cellulose hybrid fibres. Journal of Colloid and Interface Science, No. $377,88-93$

Gutierrez, J., S. C. M. Fernandes, I. Mondragon and A. Tercjak. 2013. Multifuctional hybrid nanopapers based on bacterial cellulose and sol-gel synthesized titanium/vanadium oxide nanoparticles. Cellulose, No. 20, $1301-1311$

Hon, D. N. S. 1994. Cellulose: A random walk along its historical path. Cellulose, No. 1, 1 $-25$

Hsieh, Y. C., H. Yano, M. Nogi, S. J. Eichhorn. 2008. An estimation of Young's modulus of bacterial cellulose filament. Cellulose, No. $15,507-513$

Huang L., X. Chen, T. X. Nguyen, H. Tang, L. Zhang, and G. Yang. 2013. Nano-cellulose 3D-network as controlled-release drug carriers. Journal of Materials Chemistry B, No. 1, 2976-2984

Huber, G. W., S. Ibora, and A. Corma. 2006. Synthesis of transportation fuels from biomass: Chemistry, catalisis, and engineering. Chemical Review, No. 106, $4044-4098$

Iguchi, M., S. Yamanaka, A. J. Budiono. 2000. Electrically conductive transparent papers using multiwalled carbon nanotubes. Material Science, No. 35, $261-270$
Johnson, D. C. and A. R. Winslow. 1990. Bacterial cellulose has potential application as new paper coating. Pulp and Paper, p. 105-107

Kent, R. A., R. S. Stephens, and K. J. Westland. 1991. Bacterial cellulose fiber provides an alternative for thickening and coating. Food. Technol., Vol. 45, No. 6, 108

Keshk, S., and K. Sameshina. 2006. Influence of lignosulfonate on crystal structure and productivity of bacterial cellulose in a static culture. Enzyme Microb. Technol., No. 26, $1561-1603$

Kim, J., S. W. Kim, S. Park, K. T. Lim, H. Sconwoo, Y. Kim, B. H. Hong, Y-H. Chong, and J. H. Chung. 2013. Bacterial cellulose nanofibrilar patch as a wound healing platform of tympanaic membrane perforation. Advanced Healthcare Materials, DOI: 10. 1002/ adhm.2012200368, 1 - 7

Klemm, D. D. Schumann, U. Udhardt, S. Marsch. 2001. Bacterial synthesized cellulose-artificial blood vessels for microsurgery. Prog. Polym. Sci., No. 26, 1561 $-1603$

Klemm, D., D. Schumann, F. Kramer, N. Hessler, M. Hornung, H. P. Schamuder. 2006. Nanocelluloses as innovative polymers in research and application. Advances in Polymer Science, No. 205, 49-96

Kowalska-Ludwicka, K., J. Cala, B. Grobelski, D. Sygut, D. Jesionek-Kupnicka, M. Kolodziejczyk, S. Bielecki, and Z. Pasieka. 2013. Modified bacterial cellulose tubes for regeneration of damaged peripheral nerves. Arch. Med. Sci., No. 3, $527-534$

Kulkarni, P. K., S. A. Dixit and U. B. Singh. 2012. Evaluation of bacterial cellulose produced from Acetobacter xylinum as pharmaceutical excipient. American Journal of Drug Discovery and Development, Vo. 2 , No. $2,72-86$

Lin, W. C, C. C.Lien, H. J. Yeh, C. M. Yu, and S-h Hsu. 2013. Bacterial cellulose and bacterial cellulose-chitosan membranes for wound ressing applications. Carbohydrate polymers, No. 94, $603-611$

Makela, T., T. Haatainen, P. Majander, J. Ahopelto. 2007. Continuous roll-to-roll nanoimprinting of inherently conducting polyaniline. Microelectron. Eng., No. 85, $877-880$

Maneerung T., S. Tokura, R. Rujiravanit. 2008. Impregnation of silver nanoparticles into bacterial cellulose for antimicrobial wound dressing. Carbohydrate Polymers, No. 72, $43-51$ 
Moosavi-Nasab, M. and M. Yousefi. 2011. Botechnological production of cellulose by Gluconacetobacter xylinus from agricultural waste. Iranian Journal of Biotechnology, No. 9, $94-101$

Naritomi, T., T. Kouda, H. Yano, F. Yoshinaga. 1998. Effect of lactate on bacterial cellulose production from fructose in continuous culture. Journal of Fermentation and Bioengineering, No. 85, 89 - 95

Nainggolan, H., S. Gea, E. Bilotti, T. Peijs, S. D. Hutagalung. 2013. Mechanical and thermal properties of bacterial-cellulose-fiberreinforced Mator-B1 ${ }^{\circledR}$ bionanocomposite. Beilstein Journal of Nanotechnology, No. 4, $385-329$

Nimeskern, L., H. M. Ávila, J. Sundberg, P. Gatenholm, R. Müller, K. S. Stok. 2013. Mechanical evaluation of bacterial nanocellulose as an implant material for ear cartilage replacement. Journal of the Mechanical Behavior of Biomedical Materials, No. 22, $12-21$

Nishi, Y., M. Uryu, S. Yamanaka, K. Watanabe, N. Kitamura, M. Iguchi, and S.Mitsuhashi. 1990. The structure and mechanical properties of sheet prepared from bacterial cellulose. Part 2. Improvement of the mechanical properties of sheet and their applicability to diaphragms of electroacoustic transducers. J. Mat. Sci., No. 25, 2997-3001

Nogi, M. and H. Yano. 2008. Transparent nanocomposites based on cellulose produced by bacteria offer potential innovationthe electronics device industry. Adv Mater., No. $20,1849-1852$

Norouzian, D., A. Farhangi, S. Tolooei, Z. Saffari and M. R. Mehrabi. 2011. Study nanofiber cellulose production by Glucanacetobacter xylinum ATCC 10245. Pak. J. Biol. Sci., No. $14,780-784$

Okiyama, A., M. Motoki, and S. Yamanaka. 1992. Bacterial cellulose II. Processing of the gelatinous cellulose for food materials. Food Hydrocolloids, Vol. 6, No. 5, 479-489.

Okiyama, A., M. Motoki, and S. Yamanaka. 1993. Bacterial cellulose III. Development of a new form of cellulose. Food Hydrocolloids, Vol. 6, 493-501

Oshima, T., S. Taguchi, K. Ohe, Y. Baba. 2011. Phosphorylated bacterial cellulose for adsorption of proteins. Carbohydrate Polymers, No. 83, 953 - 958

Rezaee, A., J. Derayat, H. Godini, and G. Pourtaghi. 2008. Adsorption of mercury from synthetic soutions by an Acetobacter xylinum biofilm. Res. J. Environ. Sci., No. 2, 401 - 407
Ring, D. F., W. Nashed, and T. Dow., 1986, Liquid loaded pad for medical applications, U. S. Patent No. 4,588, 400

Ross, P., R. Mayer, and M. Benziman. 1991. Cellulose biosynthesis and function in bacteria. Microbiol. Review., NO. 55, 35-58.

Ruiz-Hitzky, E., M. Darder, P. Aranda. 2007. An introduction to bio-nanohybrid materials. In: Ruiz-Hitzky, E., K. Ariga, Y. M. Lvov (eds.) Bio-inorgnic hybrid nanomaterials: strategies, syntheses, characterization and applications. Wiley-VCH Verlag $\mathrm{GmbH} \&$ Co KGaA, Weinheim, p. 1 - 40

Sanchez, P.C., 1994, Microbial aspects and quality control in nata de coco production. Forum on Nata de Coco Production for Existing Small Growers. Philippine Coconut Authority, Diliman, Quezon City, Metro Manila

Sani, A., and Y. Dahman. 2010. Improvement in the production of bacterial synthesized biocellulose nanofibers using different culture methods. Journal of Chemical Technology and Biotechnology, No. 85, 151 - 164

Sheykhnazari, S., T. Tabarsa, A. Ashori, A. Shakeri, and M. Golalipour. 2011. Bacterial synthesize cellulose nanofibers: Effect of growth times and culture mediums on the structural characteristics. Carbohydrate Polymers, No. 86, 1187 - 1191

Shi, Z., Y. Zhang, G. O. Phillips, and G. Yang. 2013. Utilization of bacterial cellulose in food. Food Hydrocolloids, No. 30, 1 - 7

Siró, I., and D. Plackett. 2010. Microfibrillated cellulose and new nanocomposite materials: review. Cellulose, No. 17, 459-494

Takai, M., F. Nonomura, T. Inukai, M. Fujiwara, and J. Hayashi. 1991. Filtration and permeation characteristic of bacterial cellulose composite. Sen"I Kagaishi, No. 47, 119-129

Wan, Y. Z., L. Hong, S. R. Jia, Y. Huang, Y. Zhu, Y. L. Wang. 2006. Synthesis and characterization of hydroxyapatite-bacterial cellulose nanocomosites. Composites Science and Technology, No. 26, $1125-1131$

Wan, Y. Z., Y. Huang, C. D. Yuan, S. Raman, Y. Zhu, H. J. Jiang, F. He, C, Gao. 2007. Biomemitic synthesis of hydroxypatite/ bacterial cellulose nanocomposites for biomedical application. Mater Sci Eng., C, No. 27, $855-864$

White, D. G. and R. M. Brown, Jr. 1989. Prospects for the commercialization of the biosynthesis of microbial cellulose. In: Schuerch (ed.), Cellulose and Wood: Chemistry and Technology p. 573-590, John Wiley and Sons, Inc., New York 
Wu, Z. Y., C. Li, H. W. Liang, J. F. Chen, and S. H. Yu. 2013. Ultralight, flexible, and fireresistant carbon nanofiber aerogels from bacterial cellulose. Angew. Chem. Int. Ed., No. 52, $2925-2929$

Yamanaka, S. 1989. Production and application of bacterial cellulose. In Inagati, $\mathrm{H}$. and G. O. Philips (eds.) Cellulosic utilization: Research and rewards in cellulose. p. 171185. Elsevier/North-Holland Publ. Co., Amsterdam
Ye, S. H., J. Watanabe, Y. Iwasaki. 2003. Antifouling blood purification membrane composed of cellulose acetate and phospholipid polymer. Baiomaterials, No. 24, $4143-4152$

Zeng, X., D. P. Small, and W. Wan. 2011. Statistical optimization of culture conditions for bacterial cellulose production by Acetobacter xylinum BPR 2001 from maple syrup. Carbohydrate Polymers, No. 85, 506 $-513$ 